\section{NOTE FROM MR. VERRAL.}

\section{To the Editor of The Lancet.}

Sir, - I seek not to prolong a controversy for which you have no room in your valuable pages, but I have some right to vindicate myself from the charge of piracy, which your own very fair observations, made without knowing the history, may appear to fix upon me.

In $1823 \mathrm{Mr}$. Bampfield published his prize essay on spinal disease. In 1823 I first invented the prone couch. I then lived far in the country. I knew nothing of Mr. Bampfield, nor he of me. We reached the same point by different roads. I formed the prone couch to suit one particular case, and finding its utility $I$ adopted the position as a system. Mr. B. has the superior merit of having adopted it as the result of reasoning and reflection. But Mr. B. proposed no prone couch, he merely laid his patients prone in their beds. So inconveniently placed, he found the position useful only in disease of the lumbar or lower dorsal vertebræ. I take a much wider range, and employ it with various modifications of the couch, not only in diseases of the spine, but also in lateral curvature, diseased hip, \&c. Besides, Mr. Bampfield's essay has, it seems, been laid on the shelf as a dead letter; at all events, his recommendation of the prone position, which $I$ only heard of a few weeks ago, has produced no effect, and appears to have remained generally unknown. Before I sent the model of my couch to the Society of Arts, I consulted my late friend $\mathrm{Mr}$. Abernethy whose reply was, that " as far as he knew, the idea was perfectly original." The surgical committee of that society must have been of the same opinion, or they would not have awarded me the medal. I envy not Mr. Bampfield's superior merit or prior claim; on the contrary, I am much gratified at finding my peculiar opinions and practice to have been partially sanctioned by the author of so excellent a work. One word to $\mathrm{Mr}$. Childs : his ignorance of the grounds upon which I charge him with piracy is very amusing - he shall, ere long, be enlightened on the subject. I am, Sir, your obedient servant,

Howland-street, April 2, 1842.

Charles Verral.

\section{UNIVERSITY COLLEGE.}

\section{To the Editor of THE LANCET.}

Sir,-I beg to lay before you my complaints, as one of the class of midwifery students at University College, on the following subject. On the death of Professor Davis, the class petitioned the council to allow his son, Dr. John Davis, to finish the course so ably begun by his father. No notice was taken of this petition by the coun- cil; but Dr. Reid was presented to their notice, without any cause being given why the class could not have their very reasonable wish gratified. However, they gave Dr. Reid a hearing, and found in him a highly. talented and honourable teacher. A report obtained currency that the council would not elect Dr. Reid to the chair. A petition was therefore commenced without delay, and signed by every pupil of the class; and, would it be believed by those who have faith in an institution based upon such liberal principles as those of University College, that the unfortunate students were again doomed to silent contempt. Now, Sir, is this just to those who have entered themselves perpetual pupils to the class, by a second payment, on the faith that as Dr. Reid had given so much satisfaction, he was to be placed permanently in the chair?

In conclusion, I beg to inform the council, that the class have determined that an explanation shall be given at Dr. Murphy's intro* ductory lecture. I am, Sir, your obedient servant,

A Pupil of University College. April 14, 1842.

\section{ROYAI, COLLEGE OF SURGEONS IN LONDON.}

Lrst of gentlemen admitted members on Friday, April 8, 1812:- Horatio Henry Handey; William Henry Horsell; John Ellerton Stocks; George Johnson; John Cuthbert Whaley; John Taylor Pearson; Samuel Waudby ; Theophilus Miller Gunn; George Marshall Phillips; Arthur Wellesley Newenham ; Frederick James Genet; John Gladdish Sanders; John Henry Hill Lewellin.

\section{TO CORRESPONDENTS.}

Studens Guyensis says (to the Editor), "I should not have replied to the criticism of ' VINDEX,' had he not made you a judge upon the case which I sent; it is therefore but right to say, that whatever $I$ wrote was perfectly true. I entreat your readers to refer to The LANCET of Feb. 12, 1842, feeling confident that they will exonerate me from the charges made by ' VInDEx.' As to the opinions I there gave, they were my own and not Dr. Ashwell's. It was quite unnecessary, therefore (to say the least of it), to bring that excellent lecturer's name forward in the criticism. The unkind manner in which "VINDEX' has written is more worthy of remark than imitation." - - ** The remarks of Vindex need not be renewed.

It is not customary to make such extracts as Mr. King suggests. We judge by description, not having seen the journal men tioned.

Communications have been received from Dr. Wilson; Dr. Hiley; and A Student of Medicine. 